\title{
Effects of taurine and housing density on renal function in laying hens"
}

\author{
Zi-li MA ${ }^{\S 1,3}$, Yang GAO $^{\S 2}$, Hai-tian MA ${ }^{1}$, Liu-hai ZHENG ${ }^{1}$, Bin DAI ${ }^{1}$, Jin-feng MIAO ${ }^{\dagger 1}$, Yuan-shu ZHANG ${ }^{1}$ \\ $\left({ }^{1}\right.$ College of Veterinary Medicine, Nanjing Agricultural University, Nanjing 210095, China) \\ ( ${ }^{2}$ Department of Orthopaedics, Qilu Hospital, Shandong University, Jinan 250012, China) \\ ( ${ }^{3}$ Animal Husbandry and Veterinary Bureau of Dongyang City in Zhejiang Province, Dongyang 322100, China) \\ ${ }^{\dagger}$ E-mail: miaojinfeng@njau.edu.cn \\ Received Jan. 8, 2016; Revision accepted Mar. 25, 2016; Crosschecked Nov. 10, 2016
}

\begin{abstract}
This study investigated the putative protective effects of supplemental 2-aminoethane sulfonic acid (taurine) and reduced housing density on renal function in laying hens. We randomly assigned fifteen thousand green-shell laying hens into three groups: a free range group, a low-density caged group, and a high-density caged group. Each group was further divided equally into a control group (C) and a taurine treatment group (T). After $15 \mathrm{~d}$, we analyzed histological changes in kidney cells, inflammatory mediator levels, oxidation and anti-oxidation levels. Experimental data revealed taurine supplementation, and rearing free range or in low-density housing can lessen morphological renal damage, inflammatory mediator levels, and oxidation levels and increase anti-oxidation levels. Our data demonstrate that taurine supplementation and a reduction in housing density can ameliorate renal impairment, increase productivity, enhance health, and promote welfare in laying hens.
\end{abstract}

Key words: Rearing pattern, Welfare, Taurine, Laying hens, Renal impairment http://dx.doi.org/10.1631/jzus.B1600014

CLC number: 5852.23

\section{Introduction}

The domestic chicken raised for meat and eggs, is an important source of animal protein for human consumption (Wicker et al., 2005). A high-density caged environment is one of the most common and economical systems employed by the commercial layer industry (Davis et al., 2000). Associated with the economic success of this system are a number of health problems, including renomegaly, hepatic lipidosis, osteoporosis, cage layer fatigue, ascites, lameness, and inflammation (Burt, 2002; Robins and

\footnotetext{
Corresponding author

$\S$ The two authors contributed equally to this work

* Project supported by the National Natural Science Foundation of China (Nos. 31372421, 31530074, and 31672515), the Fundamental Research Funds for the Central Universities (No. KYZ201415), and the Priority Academic Program Development of Jiangsu Higher Education Institutions, China

(D) ORCID: Jin-feng MIAO, http://orcid.org/0000-0001-6229-3767

(c) Zhejiang University and Springer-Verlag Berlin Heidelberg 2016
}

Phillips, 2011; Buijs et al., 2012; Dai et al., 2015; Yan, 2015).

The kidneys play an important role in various homeostatic functions via maintenance of salt and water balance, including the regulation of electrolytes, blood pressure and the maintenance of the acid-base balance (Dawson et al., 1991; Atherton, 2006; Mozaffari et al., 2006). Unlike those of mammals, the kidneys of birds usually secrete uric acid as the primary nitrogenous waste material instead of urea. The nephrons of birds have limited resorptive capacity, and the final excretory product is semi-solid rather than liquid (Dawson et al., 1991). This works for an ovigenic and volant life, but predisposes birds who lack exercise to progressive obstruction of the renal tubules and ureters, resulting in compensatory hypertrophy of the undamaged portions of the kidneys which is grossly recognized as renomegaly. The condition is common in caged laying hens fed high-protein diets. This regimen eventually causes 
oxidative, lipid metabolism disorders, and release of proinflammatory cytokines which cause renal impairment. Maintaining normal renal function is key to preserving the health, welfare, and economic sustainability of caged laying hens.

A considerable volume of research has demonstrated that nutritional regulation and exercise can ameliorate renal disease in humans. For example, dietary intake of foods rich in antioxidants can reduce the risk of renal dysfunction (Singh et al., 2006). Moinuddin and Leehey (2008) have shown that glomerular filtration rate in chronic kidney disease (CKD) could be stimulated by the increase of aerobic exercise. Toyama et al. (2010) suggested a potential link between regular exercise and improved renal function. We postulate that dietary supplementation with 2aminoethane sulfonic acid (taurine) combined with enhanced physical activity as a result of reduced housing density could improve renal impairment in laying hens.

Taurine, abundant in most animal tissues, is essential in lots of biological processes (Kadam and Prabhasankar, 2010). Although taurine can be synthesized from endogenous production, the yield is usually inadequate, and thus dietary consumption of taurine is necessary (Kadam and Prabhasankar, 2010). It has been demonstrated that taurine deficiency can lead to renal dysfunction, cardiomyopathy, developmental abnormalities, and severe damage to retinal neurons (Chesney et al., 2010; Gaucher et al., 2012). The influence of taurine on renal physiology includes renal blood flow, glomerular filtration and its rate, osmoregulation, ion reabsorption and secretion, and composition of urine, among others (Chesney et al., 2010). In our experiments, we looked into the putative positive influence of taurine and reduced housing density (increasing physical activity) on renal impairment, thus enhancing health, welfare, and productivity.

\section{Materials and methods}

\subsection{Ethics statement}

These experiments followed the guidelines of the Animal Ethics Committee of Nanjing Agricultural University (China). The procedures were compiled from the "Guidelines on Ethical Treatment of Ex- perimental Animals" (2006) No. 398 provided by the Ministry of Science and Technology (China) and the "Regulation Regarding the Management and Treatment of Experimental Animals" (2008) No. 45 provided by the Jiangsu Provincial People's Government (China).

\subsection{Animals}

Fifteen thousand green-shell laying hens were reared in the Nanjing Jinshuiwan Ecological Park (Nanjing, China). During brooding, they were reared in a shed. At 12 weeks old, they were randomly assigned to three groups: a free range group, a lowdensity caged group, and a high-density caged group. Each group was further divided into two subgroups for control treatment (C group) or taurine treatment ( $\mathrm{T}$ group) (2500 hens per group). Thus, there were six groups in total, free range ( $+/-$ taurine), low density $(+/-$ taurine), and high density (+/- taurine). The free range group was kept in two pens, one for each of the $\mathrm{C}$ and $\mathrm{T}$ groups. The high-density group consisted of five thousand hens allocated to 1666 cages, giving three hens per cage (but only two in a small cage to make sure each hen had a minimum of $351 \mathrm{~cm}^{2}$ ); the low-density groups were allocated to 2500 cages with two hens per cage $\left(526 \mathrm{~cm}^{2}\right.$ per hen). The cages/pens were the experimental units. The caged hens were under artificial lighting at temperature of $(20 \pm 3){ }^{\circ} \mathrm{C}$ and humidity of $(50 \pm 3) \%$. The free range group was housed in pastured woods during daylight and confined to indoor pens at night. All hens were water free. Dietary nutrient quantity (Table 1) was according to the recommendations of National Research Council (NRC) (1994).

\subsection{Treatment}

Laying hens in each group were fed the same basic diet. After 9 weeks ( 21 weeks old), the treatment groups were fed a $0.1 \%$ taurine diet. Fifteen days later, 10 hens in each group were humanely euthanized. Serum and kidney tissue were aseptically collected. Kidney tissue was immersed in Bouin's fixative and serum was stored at $-80^{\circ} \mathrm{C}$ until analyzed.

\subsection{Preparation of kidney tissue and serum}

Kidney samples were first weighed and homogenized with sterile physiological saline $(1: 4, \mathrm{w} / \mathrm{v})$ on ice (Kinematica AG, Switzerland); the mixture was then centrifuged at $4{ }^{\circ} \mathrm{C}(2000 \mathrm{~g}, 40 \mathrm{~min})$. The 
supernatant was collected without fat and stored at $-20^{\circ} \mathrm{C}$. The concentration of protein was determined by the Bradford method. Serum was centrifuged $(2000 \mathrm{~g}, 15 \mathrm{~min})$, and the supernatant was further collected and stored at $-20{ }^{\circ} \mathrm{C}$.

Table 1 Ingredient composition and nutrient content of diets

\begin{tabular}{|c|c|}
\hline Composition & Proportion $(\mathrm{g} / \mathrm{kg})$ \\
\hline \multicolumn{2}{|l|}{ Ingredient } \\
\hline Corn & 632 \\
\hline Wheat bran & 25 \\
\hline Soybean meal & 234 \\
\hline Limestone & 60 \\
\hline Salt & 4 \\
\hline Calcium phosphate & 17 \\
\hline DL-Methionine & 1 \\
\hline Vitamin-mineral Premix ${ }^{a}$ & 27 \\
\hline \multicolumn{2}{|l|}{ Calculated } \\
\hline $\operatorname{ME}(\mathrm{kcal} / \mathrm{kg})^{\mathrm{b}}$ & 2600 \\
\hline $\mathrm{CP}(\%)$ & 16.70 \\
\hline Calcium (\%) & 3.80 \\
\hline Lys $(\%)$ & 0.90 \\
\hline Available phosphorus (\%) & 0.46 \\
\hline \multicolumn{2}{|c|}{ 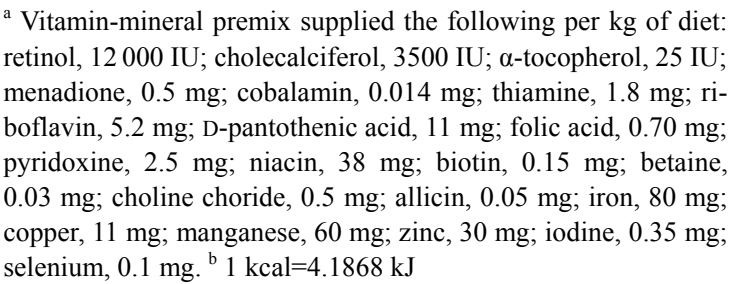 } \\
\hline
\end{tabular}

\subsection{Clinical and histologic examination}

The morphology of the kidneys was observed before the tissue was collected. Tissue specimens were fixed in Bouin's solution for $24 \mathrm{~h}$. Tissue blocks were produced via standard dehydration and paraffinwax embedding procedures and then cut into $5-\mu \mathrm{m}-$ thick serial sections. After deparaffinization and dehydration, hematoxylin and eosin ( $\mathrm{H} \& \mathrm{E})$ stained slides were prepared through standard methods.

\subsection{Quantification of SCr, BUN, SUA, NAG, GLU and iNOs}

The levels of serum creatinine ( $\mathrm{SCr}$ ), blood urea nitrogen (BUN), serum uric acid (SUA), blood glucose (GLU) and the activities of serum $N$-acetyl- $\beta$ D-glucosaminidase (NAG) and inducible nitric oxide synthase (iNOs) were evaluated using commercial kits from Nanjing Jiancheng Bioengineering Institute (Nanjing, China).
The concentrations of plasma creatinine were measured by the tungstenic acid deproteinized method. The values were calculated from the absorption of the test sample divided by the absorption of the standard sample multiplied by the $\mathrm{SCr}$ content of the standard sample expressed as $\mu \mathrm{mol} / \mathrm{L}$. BUN levels were determined using a standard diagnostic kit and expressed as $\mathrm{mmol} / \mathrm{L}$. The levels of SUA were determined by the phosphotungstic acid method and expressed as $\mu \mathrm{mol} / \mathrm{L}$. The definition of NAG enzyme activity (U) was the hydrolysis of $1 \mu \mathrm{mol} p$-nitrophenol per minute from a $1-\mathrm{L}$ reaction sample $\left(37^{\circ} \mathrm{C}\right)$.

GLU levels in serum were evaluated using the glucose oxidase method. Briefly, serum $(2 \mu \mathrm{l})$ and pre-processing working fluid $(200 \mu \mathrm{l})$ were mixed and heated for $15 \min \left(37^{\circ} \mathrm{C}\right)$ and absorbance measured at $505 \mathrm{~nm}$. Serum GLU was calculated by the absorption of the test sample divided by the absorption of the standard sample multiplied by the glucose content of the standard sample and expressed as mmol/L.

iNOs activity in kidney homogenates was evaluated. Briefly, the sample was incubated with $0.6 \mathrm{ml}$ of reaction buffer $\left(5 \mathrm{mmol} / \mathrm{L} \mathrm{MgCl}_{2}, 250 \mathrm{mmol} / \mathrm{L}\right.$ L-valine, $0.2 \mathrm{~mol} / \mathrm{L}$ phosphate buffered saline (PBS), $480 \mu \mathrm{mol} / \mathrm{L}$ oxyhemoglobin, and $30 \mathrm{mmol} / \mathrm{L}$ nicotinamide adenine dinucleotide phosphate (NADPH)), combined with an iNOs inhibitor $(6 \mathrm{mmol} / \mathrm{L}$ ethylene glycol tetraacetic acid (EGTA)). After $15 \mathrm{~min}$, the reaction was terminated with $10 \mathrm{mmol} / \mathrm{L}$ ethylene diamine tetraacetic acid (EDTA) and $10 \mathrm{mmol} / \mathrm{L}$ 4-(2-hydroxyethyl)-1-piperazineethanesulfonic acid (HEPES) buffer at $37^{\circ} \mathrm{C}$. The colored compound was photometrically measured at a wavelength of $530 \mathrm{~nm}$. iNOs activity was evaluated and expressed as $\mathrm{U} / \mathrm{g}$ protein (kidney tissue).

\subsection{Analyses of T-AOC, SOD, and MDA}

The activities of superoxide dismutase (SOD) and levels of total anti-oxidation capability (T-AOC), and malondialdehyde (MDA) in kidney homogenate were assayed using commercial kits from Nanjing Jiancheng Bioengineering Institute (Nanjing, China). The data were evaluated following the manufacturer's protocols. Briefly, the T-AOC of the reaction mixture was measured at $37{ }^{\circ} \mathrm{C}$ every minute through the absorbance at $520 \mathrm{~nm}$ per $\mathrm{mg}$ protein and expressed as $\mathrm{U} / \mathrm{mg}$ protein. The definition of SOD activity was the amount that reduced the absorbance by $50 \%$ at 
$550 \mathrm{~nm}$ and expressed as U/mg protein. MDA expressed as nmol/mg protein was determined by the thiobarbituric acid reaction (TBAR) method.

\subsection{Electrophoretic mobility shift assay (EMSA)}

The nuclear factor (NF)- $\kappa \mathrm{B}$ probe with a sequence of 5'-AGT TGA GGG GAC TTT CCC AGG C-biotin-3' was used as a probe, which was labeled by the Biotin labeling kit (Pierce, Rockford, IL, USA). The labeled probe and $15 \mu \mathrm{g}$ of nuclear extract were mixed in the binding buffer until a volume of $20 \mu \mathrm{l}$ was reached at room temperature. After incubation for $30 \mathrm{~min}$, the sample was gently mixed with loading buffer. The samples were loaded onto a 5\% nondenaturing polyacrylamide gel with $0.5 \times$ Tris-borate/ EDTA (TBE) on ice and electrophoresis at $80 \mathrm{~V}$. Then the proteins in the gel were transferred to a nylon membrane (Millipore, Bedford, MA, USA), and DNA was cross-linked to the membrane for $10 \mathrm{~min}$ by a ultraviolet (UV)-light. According the manufacturer's protocols, binding DNA was detected by enhanced chemiluminescence (Pierce, USA) and quantified by scanning densitometry (Genomic Solutions, Ann Arbor, MI, USA). The results for the binding activity between NF- $\mathrm{BB}$ and DNA were expressed as relative integrated intensity contrasted with the free range control group (defined as standard).

\subsection{RNA extraction and reverse transcription- polymerase chain reaction (RT-PCR)}

\subsubsection{RNA extraction}

Total RNA was isolated using the TRIzol reagent (TaKaRa, Dalian, China). The concentration was determined by UV-visible (UV-vis) absorbance at a wavelength of $260 \mathrm{~nm}$ (Eppendorf Biophotometer).

\subsubsection{Real-time quantitative RT-PCR}

Reverse transcriptase was performed using the RNA $(2 \mu \mathrm{g})$. Ten units avian myeloblastosis virus (AMV) reverse transcriptase, $20 \mathrm{U}$ recombinant RNasin ribonuclease inhibitor, $1 \mathrm{mmol} / \mathrm{L}$ dNTP mixture, and 50 pmol Oligo(dT) $)_{18}$ primer were added into the reaction tube until the final volume reached $20 \mu \mathrm{l}$. The reaction tube was incubated at $42^{\circ} \mathrm{C}$ for $1 \mathrm{~h}$ and then heated at $95^{\circ} \mathrm{C}$ for $5 \mathrm{~min}$. An aliquot of the complementary DNA was mixed with $25 \mu \mathrm{S} \mathrm{SYBR}{ }^{\circledR}$ Green PCR Master Mix (TaKaRa, Dalian, China) in the presence of 10 pmol forward and reverse primers for tumor necrosis factor (TNF)- $\alpha$, interferon (IFN)- $\gamma$, interleukin (IL)-4, IL-10, and peroxisome proliferator receptor- $\alpha$ (PPAR- $\alpha$ ) (Table 2), which was subjected to PCR under standard conditions (43 cycles). The RT products were added to PCR in the presence of the primers specific for chicken $\beta$-actin as an internal control. All sequences of the primers were synthesized by the Invitrogen Biological Company (Shanghai, China). All samples were analyzed in an ABI Prism 7300 Sequence Detection System (Applied Biosystems, Weiterstadt, Germany), which was programmed as follows: one cycle at $95^{\circ} \mathrm{C}$ for $10 \mathrm{~min}, 43$ cycles at $95^{\circ} \mathrm{C}$ for $15 \mathrm{~s}$, and $62{ }^{\circ} \mathrm{C}$ for $1 \mathrm{~min}$. The results were expressed as in this previous report (Miao et al., 2013).

\subsection{Detection of TNF- $\alpha$ levels by ELISA}

Renal tissue levels of TNF- $\alpha$ were measured by enzyme-linked immunosorbent assay (ELISA) kits (Beijing Rigorbio Science Development Company, Beijing, China; http://www.bt-laboratory.com/productlist. asp?id=25858). The renal tissue was taken out of the fridge at $2-8{ }^{\circ} \mathrm{C}$ and left for $30 \mathrm{~min}$ at ambient temperature before use. Briefly, prepared standards $(50 \mu \mathrm{l})$

Table 2 Primer sequences of targeted genes and $\beta$-actin

\begin{tabular}{clll}
\hline Gene & Accession number & \multicolumn{1}{c}{ Primer sequence $\left(5^{\prime} \rightarrow 3^{\prime}\right)$} & Orientation \\
\hline$\beta$ - actin & L08165 & TGCGTGACATCAAGGAGAAG & Forward \\
& & TGCCAGGGTACATTGTGGTA & Reverse \\
$P P A R-\alpha$ & AF470455 & TGGACGAATGCCAAGGTC & Forward \\
& & RATTTCCTGCAGTAAAGGGTG & Forward \\
$T N F-\alpha$ & \multirow{2}{*}{ N942589.1 } & GATGGGAAGGGAATGA & Reverse \\
& & ACAGGAAGGGCAACTC & Forward \\
$I F N-\gamma$ & NM205149.1 & GAGCCATCACCAAGAA & Reverse \\
& & ATAGGTCCACCGTCAG & Forward \\
$I L-4$ & GU119892.1 & CAGCACTGCCACAAGA & Reverse \\
& & AGTTGGTGGAAGAAGGTA & Forward \\
$I L-10$ & NM001004414.2 & GCTGAGGGTGAAGTTTG & Reverse \\
\hline
\end{tabular}


were reacted for $60 \mathrm{~min}$ at $37^{\circ} \mathrm{C}$ with corresponding antibodies $(40 \mu \mathrm{l})$ labeled with enzyme $(10 \mu \mathrm{l})$ and washed 5 times. Then chromogen solutions A $(50 \mu \mathrm{l})$ and $\mathrm{B}(50 \mu \mathrm{l})$ were added to each well and mixed gently and incubated for $10 \mathrm{~min}$ at $37^{\circ} \mathrm{C}$ in the dark. The reaction was stopped using stop solution $(50 \mu \mathrm{l})$ in each well and the optical density (OD) measured at a wavelength of $450 \mathrm{~nm}$ within $10 \mathrm{~min}$. The standard linear regression equation was calculated from the relationship between the standard concentrations and the corresponding OD values. Based on the regression equation, the concentration of the corresponding samples could be calculated. The concentrations of TNF- $\alpha$ were expressed as ng/g protein.

\subsection{Statistical analyses}

All statistical data analyses were computed using statistical software SPSS 17.0. Data were presented as single points with mean \pm standard error of mean (SEM). Differences were considered significant at the value of $P<0.05$.

\section{Results}

\subsection{Clinical and histologic examination}

The clinical pictures show irregular hypertrophy of the kidneys in the high-density housing $\mathrm{C}$ group (Fig. 1a). In the free range group, the kidneys were normal in both $\mathrm{C}$ and $\mathrm{T}$ groups (Figs. $1 \mathrm{~b}$ and $1 \mathrm{c}$ ).

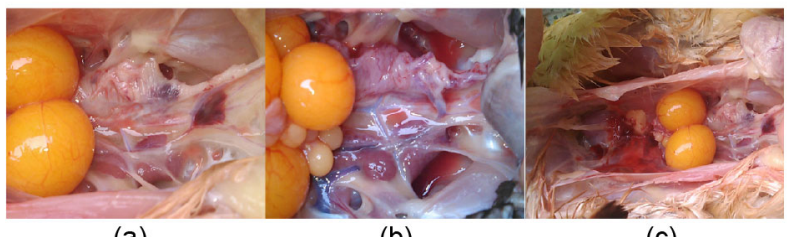

(a)

(b)

(c)

Fig. 1 Clinical photos of laying hens

(a) High-density housing control group; (b) Free range control group; (c) Free range taurine treatment group

In the free range $\mathrm{C}$ group, kidney structures were normal with intact tubules, and have no histological abnormalities, apoptosis, necrosis, or infiltration of inflammatory cells. In the high-density housing $\mathrm{C}$ group, tubules were ectatic. In the low-density housing $\mathrm{C}$ group, there were very few dilated tubules (Fig. 2a).
Dietary taurine supplementation ameliorated renal lesions, especially in the high-density housing $\mathrm{T}$ group. In low-density housing groups, the histological renal structures were similar to those in controls (Fig. 2b).
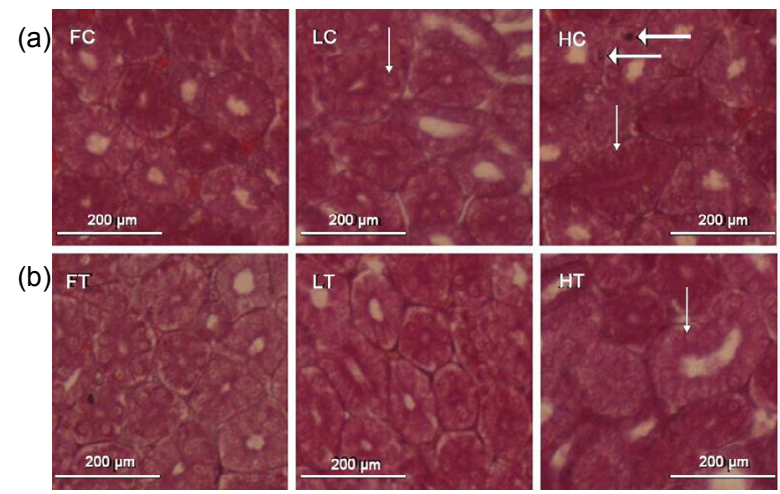

Fig. 2 Histology of the kidney in laying hens Renal sections were stained with $\mathrm{H} \& \mathrm{E}$ (original magnification $200 \times$ ). FC: free range control group; FT: free range taurine treatment group; LC: low-density housing control group; LT: low-density housing taurine treatment group; HC: highdensity housing control group; HT: high-density housing taurine treatment group. Arrows point to ectatic tubules. Thick arrows point to inflammatory cells

\subsection{Changes in SCr, BUN, SUA, and NAG}

The difference in SCr content between the $\mathrm{C}$ and $\mathrm{T}$ groups was not statistically significant. In the highdensity housing group, SCr content drastically decreased in the $\mathrm{T}$ group compared with the $\mathrm{C}$ group $(P<0.05$; Fig. $3 a)$. BUN in the free range group was lower than that in the low- and high-density housing control groups $(P<0.05)$. BUN levels between the free range and high-density $\mathrm{T}$ groups had a similar trend $(P<0.05)$. BUN concentration in the $\mathrm{T}$ groups was reduced compared with the $\mathrm{C}$ groups (Fig. $3 \mathrm{~b}$ ). In the $\mathrm{C}$ groups, SUA in the high-density housing group was significantly higher than that in the free range and low-density housing groups $(P<0.05)$, but there was very little difference between the $\mathrm{T}$ groups. In the high-density housing group supplemented with taurine, there was a significantly decreased SUA content $(P<0.05$; Fig. $3 \mathrm{c})$. Serum NAG activity in the free range group was markedly lower than that in the low-density and high-density housing $\mathrm{C}$ and $\mathrm{T}$ groups $(P<0.05)$. Moreover, in $\mathrm{C}$ groups, serum NAG activity in the low-density housing group markedly declined compared to the high-density housing group $(P<0.05)$. Taurine markedly decreased the activity of serum NAG in the high-density housing group ( $P<0.05$; Fig. $3 \mathrm{~d})$. 


\subsection{Blood glucose analysis}

In the $\mathrm{C}$ group, the concentration of serum GLU in the high-density housing group was higher than that in the free range $(P<0.05)$. In the T groups, there was nearly no difference. Relative to $C$, there was a significant reduction in the high-density housing $\mathrm{T}$ group $(P<0.05$; Fig. 3e).

\subsection{SOD activity, T-AOC and MDA levels in kidney}

Relative to C, MDA levels in T decreased (Fig. 4a). SOD activities in the free range group were higher than those in the low-density and high-density housing groups. In the $\mathrm{C}$ groups, $\mathrm{SOD}$ activities in the free range and low-density housing groups were higher

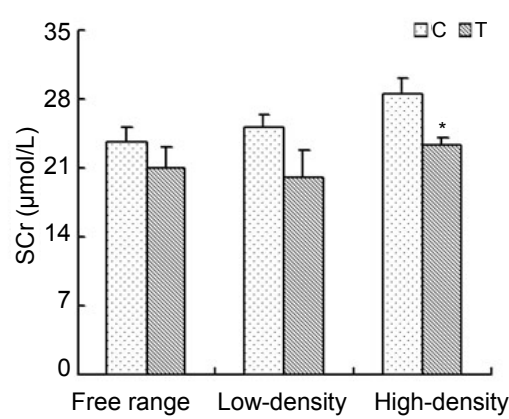

(a)

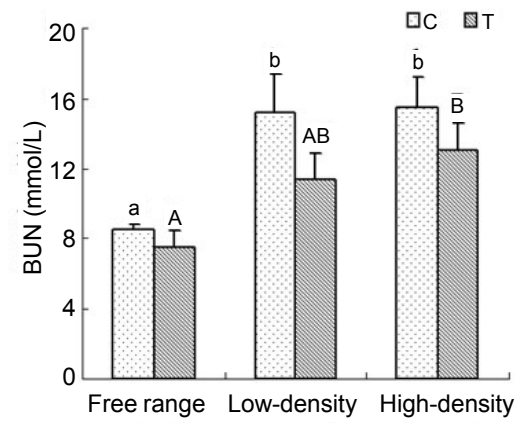

(b)

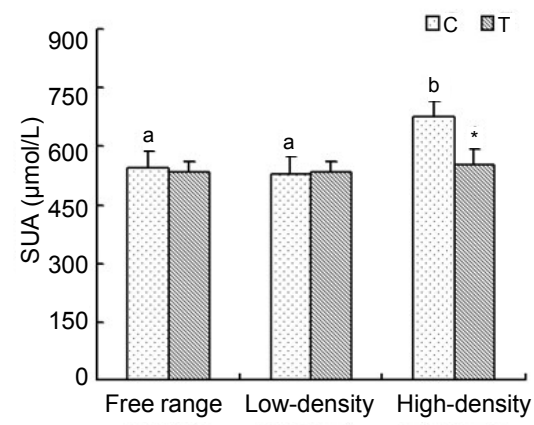

(c)

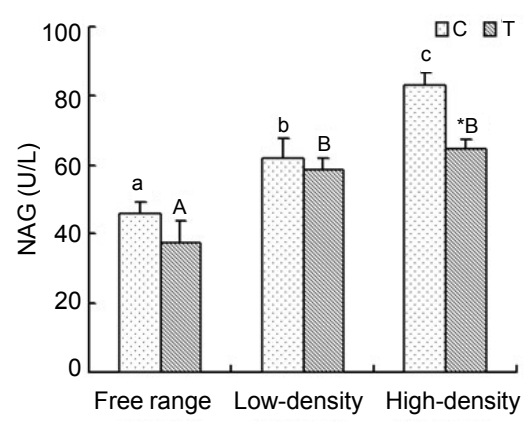

(d)

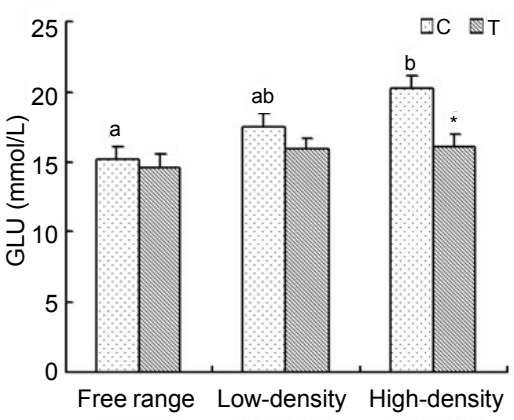

(e)

Fig. 3 SCr, BUN, SUA, NAG, and GLU levels

Data are presented as mean $\pm \operatorname{SEM}(n=10) .{ }^{*} P<0.05$, significant difference between control and treatment groups in the same rearing regimen. Superscripts not sharing a common letter differ significantly (small letter for control groups and capital letter for treatment groups) at $P<0.05$. (a) SCr; (b) BUN; (c) SUA; (d) NAG; (e) GLU

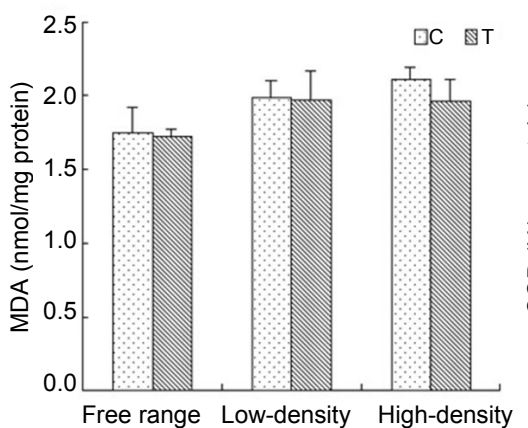

(a)

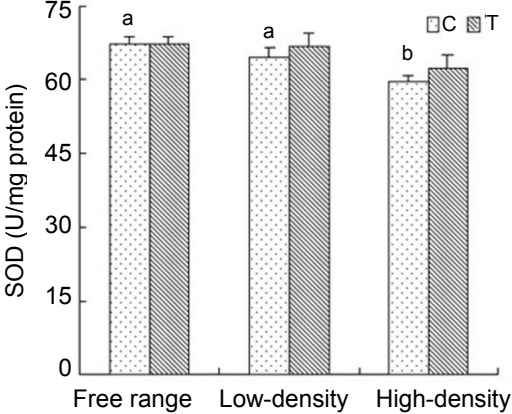

(b)

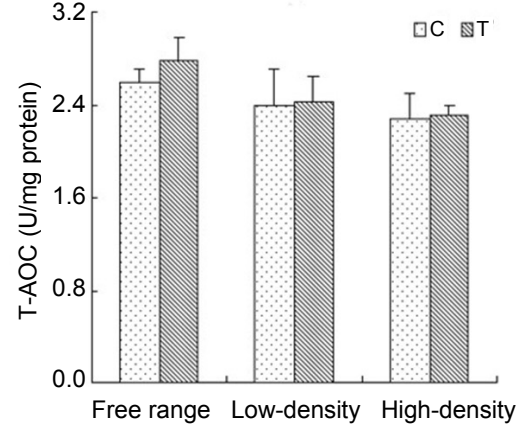

(c)

Fig. 4 Changes in SOD activity, T-AOC and MDA levels in the kidney

Kidneys were collected and SOD (b) activity, MDA (a) and T-AOC (c) levels were determined using commercial kits. Data are presented as the mean \pm SEM $(n=10)$. Superscripts not sharing a common letter differ significantly (small letter for control groups) at $P<0.05$ 
than those in the high-density housing group $(P<0.05)$ Relative to C, SOD activity had an increasing trend, although there was no significant variability (Fig. 4b). Compared to C, T-AOC levels in T increased (Fig. 4c).

\subsection{Effects of taurine and rearing modes on NF-кB DNA binding activity in kidney}

The binding activities between NF- $\mathrm{B}$ and DNA in the low-density and high-density housing groups increased significantly compared to the free range $\mathrm{C}$ group $(P<0.05)$. In the $\mathrm{T}$ groups, there was a marked elevation in the high-density housing group in contrast to the free range and low-density housing groups $(P<0.05)$. Taurine significantly decreased the binding activity between NF- $\mathrm{NB}$ and DNA in the low-density housing group $(P<0.05$; Fig. 5b).

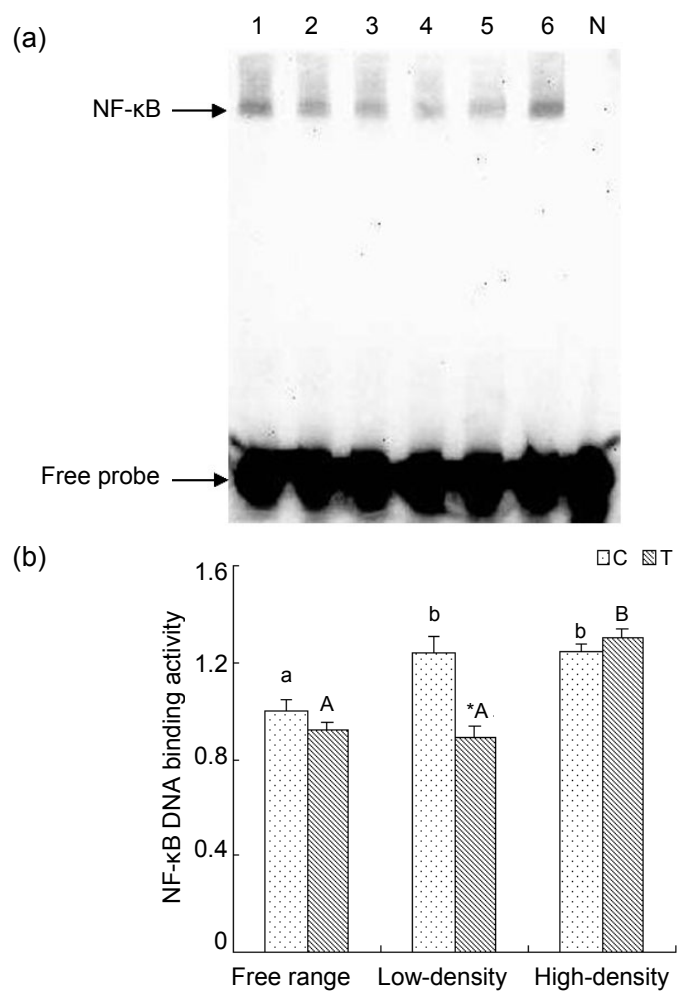

Fig. 5 Effect of taurine on NF-кB DNA binding activity by EMSA analysis in renal tissue from laying hens

(a) Lanes 1 and 2 are control and treatment groups in free range environment; Lanes 3 and 4 are control and treatment groups in low-density caged environment; Lanes 5 and 6 are control and treatment groups in high-density caged environment; Lane $\mathrm{N}$ is negative control. (b) Results of statistical analysis for NF- $\kappa \mathrm{B}$ DNA binding activities. Data are presented as the mean \pm SEM $(n=10) .{ }^{*} P<0.05$, significant difference between the control and treatment groups in the same rearing pattern. Superscripts not sharing a common letter differ significantly (small letter for control groups and capital letter for treatment groups) at $P<0.05$
3.6 Renal expressions of TNF- $\alpha$, IFN- $\gamma$, IL-4, IL-10, and PPAR- $\alpha$ mRNA

Compared with the free range and low-density housing groups, the mRNA expression of TNF- $\alpha$ in the high-density housing $\mathrm{C}$ group increased significantly $(P<0.05)$. Significant increases were also observed in the low-density and high-density housing groups compared to the free range group $(P<0.05)$. Taurine reduced the expression of TNF- $\alpha$ mRNA in the free range and high-density housing groups significantly $(P<0.05$; Fig. 6a). In the high-density housing group, IFN- $\gamma$ mRNA expression increased significantly compared with the free range and lowdensity housing $\mathrm{C}$ groups $(P<0.05)$. The changes in $\mathrm{T}$ groups were not significant. Taurine supplementation markedly decreased IFN- $\gamma$ mRNA expression in each rearing pattern $(P<0.05$; Fig. $6 b)$. IL-4 mRNA expression peaked in the high-density housing $\mathrm{C}$ groups $(P<0.05)$. There was no significant variability in the $\mathrm{T}$ groups. Taurine significantly reduced IL-4 mRNA expression in the different rearing patterns $(P<0.05$; Fig. 6c). In the high-density housing groups, IL-10 mRNA expression increased significantly compared with the free range and low-density housing $\mathrm{C}$ and $\mathrm{T}$ groups $(P<0.05)$. Marked differences were present in the low-density and high-density housing groups $(P<0.05$; Fig. 6d). No significant differences were found in the $\mathrm{C}$ groups in PPAR- $\alpha$ mRNA expression. In the $T$ groups, PPAR- $\alpha$ mRNA expression in the free range group was higher than that in the highdensity housing group $(P<0.05)$. Relative to $\mathrm{C}$, significant elevation was found in the low-density housing group $(P<0.05$; Fig. $6 \mathrm{e})$.

\subsection{Changes in renal iNOs activity}

Renal iNOs activity in the high-density housing group increased significantly compared to the free range and low-density housing $\mathrm{C}$ and $\mathrm{T}$ groups $(P<0.05)$. No significant difference was found between $\mathrm{C}$ and $\mathrm{T}$ in each rearing pattern (Fig. 7a).

\subsection{Changes in renal TNF- $\alpha$ levels}

TNF- $\alpha$ level did not change in the $\mathrm{C}$ groups. TNF- $\alpha$ level in the free range group was lower than that in the low-density and high-density housing $\mathrm{T}$ groups $(P<0.05)$. No significant differences were found between the $\mathrm{C}$ and $\mathrm{T}$ groups in the same rearing pattern (Fig. 7b). 


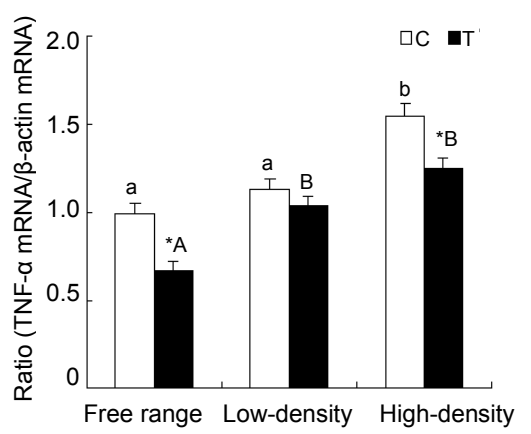

(a)

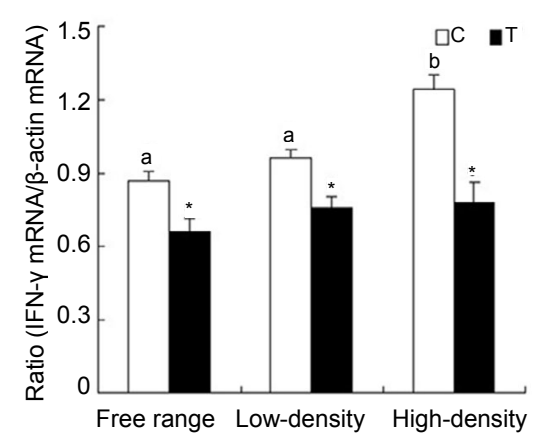

(b)

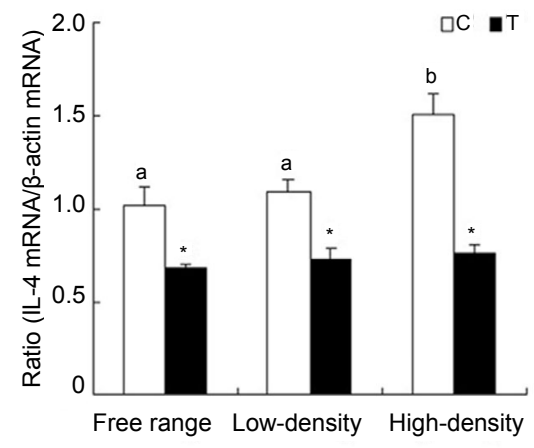

(c)

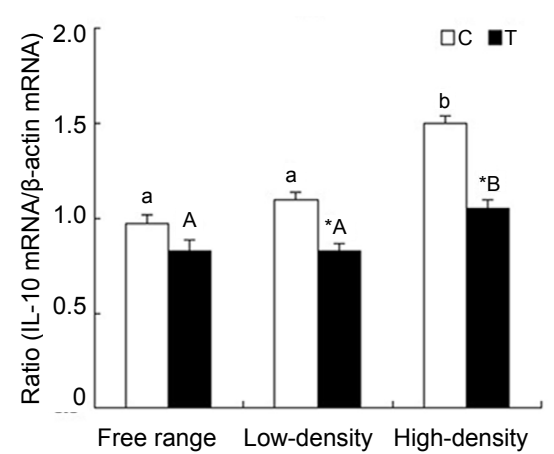

(d)

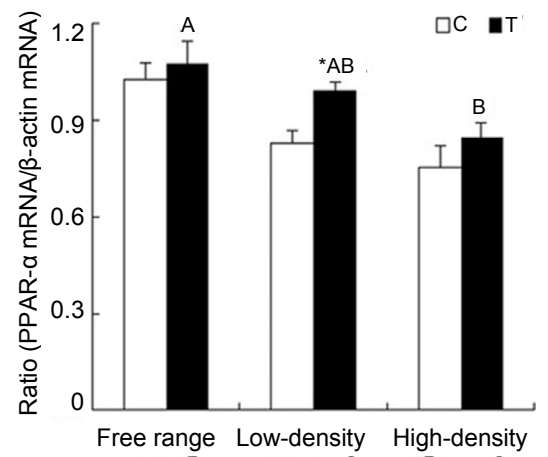

(e)

Fig. 6 Changes in TNF- $\alpha$, IFN- $\gamma$, IL-4, IL-10 and PPAR- $\alpha$ gene expression in laying hen kidneys

The expression level of each gene was determined by real-time RT-PCR, and the expressed RNA levels were normalized to $\beta$-actin as a ratio of gene of interest $/ \beta$-actin mRNA levels. Data are presented as mean $\pm \operatorname{SEM}(n=10) .{ }^{*} P<0.05$, significant difference between the control and treatment groups in the same rearing pattern. Superscripts not sharing a common letter differ significantly (small letter for control groups and capital letter for treatment groups) at $P<0.05$. (a) TNF- $\alpha$; (b) IFN- $\gamma$; (c) IL-4; (d) IL-10; (e) PPAR- $\alpha$

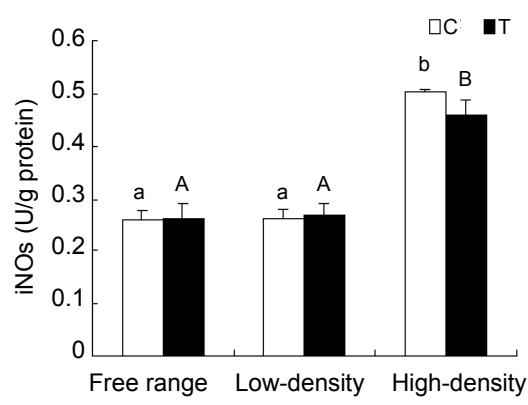

(a)

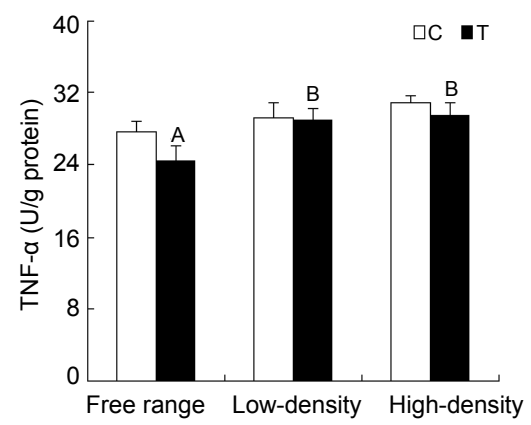

(b)

Fig. 7 Changes in iNOs and TNF- $\alpha$ levels in the kidneys of laying hen

Data are presented as mean $\pm \operatorname{SEM}(n=10)$. Superscripts not sharing a common letter differ significantly (small letter for control groups and capital letter for treatment groups) at $P<0.05$. (a) iNOs; (b) TNF- $\alpha$

\section{Discussion}

The special function of kidney in birds leads to compensatory hypertrophy of the undamaged portions of the kidneys, which is grossly recognized as renomegaly. Renomegaly has been the most common disease in caged domestic chicken (Burt, 2002; Robins and Phillips, 2011; Buijs et al., 2012). In our 
experiments, renal tubules had morphologic lesions in groups raised in high-density conditions compared with the free range and low-density housing groups. Taurine supplementation ameliorated these lesions. This indicates that renal function in the high-density rearing pattern was impaired and taurine plays a protective role in reducing tissue damage.

In clinical practice, $\mathrm{SCr}, \mathrm{BUN}$, and NAG levels/ activity are commonly used to assess renal function (Hu et al., 2009; Wang et al., 2011). We found that the concentrations of SCr and BUN, and NAG activity were higher in hens with histologic evidence of nephropathy (Wang et al., 2011). SCr and BUN concentrations and NAG activity in high-density housing groups were higher than those in the free range and low-density housing groups. Treatment with taurine prevented the elevation of these parameters. The higher levels of SCr, BUN, and NAG indicated that renal function was impaired in the high-density housing group. Low-density and free range housing groups and those groups with taurine supplementation had lower values. Lower BUN levels indicate better renal function and fewer kidney lesions in animal models and birds (Nirala and Bhadauria, 2008; Nirala et al., 2008). Consequently, kidney structure and function in the low-density housing and free range groups and those groups administrated with taurine indicate that taurine supplementation and uncrowded housing are palliative. The biochemical and histologic findings reinforce each other.

Many human conditions, such as gouty arthritis, metabolic syndrome, insulin resistance, kidney stones, and cardiovascular disease, are caused by excessive plasma urate (Cirillo et al., 2006; Nakagawa et al., 2006). The balance of production and excretion is indispensable for the control of blood urate. In the current study, we observed a decrease in uric acid concentration in serum with a reduction in housing density; taurine supplementation brought it down further. This suggests that reduced housing density and taurine can protect renal structure and function. GLU metabolism is also related to renal function. A high concentration of GLU increases kidney load, and excessive, long loads result in functional impairment (Lin et al., 2010). In our study, fasting GLU concentration was significantly elevated in high-density housing $\mathrm{C}$ groups. Taurine decreased the GLU concentration, especially in the high-density group. Lin et al. (2010) demonstrated that taurine effectively reduced GLU, preventing the development and occurrence of diabetic nephropathy. Kidney load in the free range and low-density housing groups was lower, indicating that taurine diminished the load.

It has been proved that many human diseases are related to high levels of oxidative stress and the overproduction of reactive oxygen species, such as cardiovascular disease, diabetes-induced renal injury, and enhanced lipid peroxidation (Kaneko et al., 2007; Hamden et al., 2009). In many studies, taurine was used to protect cells from oxidative damage and reduce apoptosis (Lakshmi Devi and Anuradha, 2010; Das et al., 2012). Many articles have shown that oxidative stress has a negative influence on polycystic kidney disease (Rodrigo and Rivera, 2002). How taurine affects the oxidation and antioxidant levels of kidney is an important outcome of our study. T-AOC levels reflect the efficacy of free radical scavenging. The redox balance of the intracellular environment is regulated by a series of antioxidant systems. SOD is one of the main antioxidant enzymes and can catalyze $\mathrm{O}^{2-}$ disproportionately into $\mathrm{H}_{2} \mathrm{O}_{2}$ and $\mathrm{O}_{2}$. Reduction of SOD activity may increase peroxide which is followed by changes in molecular structure resulting in cell destruction (Tian et al., 2011). The results from the current study show that taurine supplementation may increase SOD activity and T-AOC levels in kidney tissue in three poultry rearing systems. SOD activity and T-AOC levels among high-density housed birds were lower than those in free range and low-density housed groups.

The common index for evaluating oxidative stress is MDA (Parikh et al., 2003; Wu et al., 2012). In the present study, MDA levels decreased in the taurine treatment groups, and MDA levels in the kidneys of birds reared in high-density housing were higher than those in free range birds or those reared at low densities. The data show that dietary taurine supplementation and reduced housing density could reduce oxidative stress and enhance antioxidant levels, thus protecting kidneys from oxidative damage.

Inflammatory disease is also influenced by an excess of reactive oxygen species (Hanna et al., 2004). Appropriate inflammation can protect the body against viruses and other unfavorable factors (Keller et al., 2011), but excessive levels of inflammation are associated with increasing severity of CKD in human 
patients (Al-Saady et al., 1999; Oberg et al., 2004). We speculated that renal impairment in laying hens resulted from an increase in inflammation. Therefore, we assayed renal inflammatory mediator levels. $\mathrm{NF}-\kappa \mathrm{B}$, a constitutively expressed transcription factor, plays a central role in regulating the response to stress. Classically, the NF-kB-mediated signaling pathway has been considered both proinflammatory and antiapoptotic and has been associated with the pathogenesis of a wide variety of diseases, including inflammatory disorders and tumorigenesis (Baker et al., 2011; He and Karin, 2011). Activated NF- $\mathrm{kB}$ is an important factor in upregulation of pro-inflammatory cytokines (Chowdhry et al., 2010). In the current

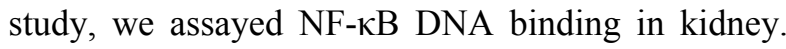
The data show that taurine down-regulated NF- $\mathrm{KB}$ DNA binding. Moreover, NF- $\mathrm{kB}$ DNA binding activity in the free range and low-density housing groups was lower than that in the high-density housing group. It appears that suppression of the inflammatory reaction, as reflected by NF- $\mathrm{kB}$, is attributable to taurine supplementation and reduced housing density. Our results are supported by a previous study showing that taurine can inhibit NF- $\mathrm{kB}$ activation (Sun et al., 2012). Treatment with taurine and reducing housing density down-regulates NF- $\mathrm{kB}$ and inhibits the expression of the NF-kB-driven inflammatory mediators.

NF- $\kappa B$ regulates the syntheses of TNF- $\alpha$, IL- $1 \beta$, iNOs, and other mediators (Kumar et al., 2004; Ridder and Schwaninger, 2009). We assayed TNF- $\alpha$ level, mRNA expression, and iNOs activity in kidney tissue. Not all these factors changed significantly in all groups. We found TNF- $\alpha$ level, mRNA expression, and iNOs activity in renal tissue increased in the high-density housing group in comparison to the free range and low-density housing groups. Inflammatory mediators from the low-density housing and free range groups were lower and we conclude that decreasing rearing density is, in part, responsible for this phenomenon. Dietary taurine decreased TNF- $\alpha$ mRNA expression and the activity of iNOs in kidney. These results are in agreement with Das and Sil (2012) and demonstrate that taurine supplementation attenuates renal inflammation.

The status of the immune system is an important measure in evaluating health and welfare. $\mathrm{CD}^{+} \mathrm{T}$ helper (Th) lymphocytes are integral for an effective immune response. On the basis of their distinct cytokine profiles, $\mathrm{CD} 4{ }^{+} \mathrm{T}$ cells have been classified into two major types, Th1 and Th2 (Crews et al., 2006; Miao et al., 2009). INF- $\gamma$ is one of the main proinflammatory Th1 cytokines (Abbas et al., 1996). The present study documents that INF- $\gamma$ levels and mRNA expression in kidneys were elevated most in the high-density housing group. Laying hens housed in low-density and free range conditions had lower Th1 cytokine levels. Taurine supplementation decreased renal INF- $\gamma$ mRNA expression. Since taurine has been shown to suppress Th1-type immunity (Wirleitner et al., 2004), these data indicate that low-density housing and taurine supplementation may inhibit the overexpression of Th1 cytokines in laying hens.

IL-4 and IL-10 are the main anti-inflammatory cytokines and are a reflection of renal Th2 cytokines (Abbas et al., 1996). In the current study, IL-4 and IL-10 mRNA expressions in renal tissue were higher in the high-density housing group and lower in the low-density and free range housing groups. Dietary taurine supplementation lowered mRNA expression and IL-4 and IL-10 levels. As a result of the current study, we believe that reducing rearing density and supplementing the birds with dietary taurine may protect the kidney against damage by enhancing the immune defense system.

PPAR- $\alpha$ regulates both lipid metabolism and inflammation (Guan and Breyer, 2001). The activation of PPAR- $\alpha$ significantly decreases triglycerides and appropriately reduces total cholesterol and lowdensity lipoprotein (LDL) levels, and elevates highdensity lipoprotein (HDL) levels (Ansquer et al., 2009). In the current study, PPAR- $\alpha$ mRNA expression in the free range group was higher than that in the high-density group. Taurine up-regulated the expression of PPAR- $\alpha$ mRNA in renal tissue. This suggests that kidneys in the free range and taurine treatment groups were better protected.

In conclusion, the impairment of kidney function in the high-density housing group may be because of a combination of the inflammatory cascade and oxidative stress (Rouach et al., 1997; Rodrigo and Rivera, 2002; Deiana et al., 2008; Keller et al., 2011). Our data show that low-density and free range rearing as well as dietary supplementation with taurine can ameliorate the impairment of kidney function by decreasing inflammation, augmenting the immune 
system, and alleviating oxidative stress. Here, dietary taurine can be used to protect renal function, enhance health, and promote the welfare and productivity of laying hens in the commercial poultry industry, so can reduced housing density.

\section{Acknowledgements}

The authors express their thanks to Dr. Howard GELBERG (Oregon State University, USA) for manuscript editing.

\section{Compliance with ethics guidelines}

Zi-li MA, Yang GAO, Hai-tian MA, Liu-hai ZHENG, Bin DAI, Jin-feng MIAO, and Yuan-shu ZHANG declared that they have no conflict of interest.

All institutional and national guidelines for the care and use of laboratory animals were followed.

\section{References}

Abbas, A.K., Murphy, K.M., Sher, A., 1996. Functional diversity of helper T lymphocytes. Nature, 383(6603): 787-793.

http://dx.doi.org/10.1038/383787a0

Al-Saady, N., Leatham, E., Gupta, S., et al., 1999. Monocyte expression of tissue factor and adhesion molecules: the link with accelerated coronary artery disease in patients with chronic renal failure. Heart, 81(2):134-140. http://dx.doi.org/10.1136/hrt.81.2.134

Ansquer, J., Foucher, C., Aubonnet, P., et al., 2009. Fibrates and microvascular complications in diabetes-insight from the FIELD study. Curr. Pharm. Design, 15(5):537-552. http://dx.doi.org/10.2174/138161209787315701

Atherton, J.C., 2006. Role of the kidney in acid-base balance. Anaesth. Intens. Care Med., 7(7):276-278. http://dx.doi.org/10.1053/j.mpaic.2006.04.008

Baker, R.G., Hayden, M.S., Ghosh, S., 2011. NF-кB, inflammation, and metabolic disease. Cell Metab., 13(1):11-22. http://dx.doi.org/10.1016/j.cmet.2010.12.008

Buijs, S., van Poucke, E., van Dongen, S., et al., 2012. The influence of stocking density on broiler chicken bone quality and fluctuating asymmetry. Poult. Sci., 91(8): 1759-1767.

http://dx.doi.org/10.3382/ps.2011-01859

Burt, D., 2002. Applications of biotechnology in the poultry industry. Worlds Poult. Sci. J., 58:5-13. http://dx.doi.org/10.1079/WPS20020002

Chesney, R.W., Han, X., Patters, A.B., 2010. Taurine and the renal system. J. Biomed. Sci., 17(Suppl. 1):S4. http://dx.doi.org/10.1186/1423-0127-17-S1-S4

Chowdhry, S., Nazmy, M.H., Meakin, P.J., et al., 2010. Loss of Nrf2 markedly exacerbates nonalcoholic steatohepatitis. Free Radical Biol. Med., 48(2):357-371. http://dx.doi.org/10.1016/j.freeradbiomed.2009.11.007

Cirillo, P., Sato, W., Reungjui, S., et al., 2006. Uric acid, the metabolic syndrome, and renal disease. J. Am. Soc. Nephrol., 17(12 Suppl. 3):S165-S168.
http://dx.doi.org/10.1681/ASN.2006080909

Crews, F.T., Bechara, R., Brown, L.A., et al., 2006. Cytokines and alcohol. Alcohol Clin. Exp. Res., 30(4):720-730. http://dx.doi.org/10.1111/j.1530-0277.2006.00084.x

Dai, B., Zhang, Y., Ma, Z., et al., 2015. Influence of dietary taurine and housing density on oviduct function in laying hens. J. Zhejiang Univ.-Sci. B (Biomed. \& Biotechnol.), 16(6):456-464.

http://dx.doi.org/10.1631/jzus.B1400256

Das, J., Sil, P.C., 2012. Taurine ameliorates alloxan-induced diabetic renal injury, oxidative stress-related signaling pathways and apoptosis in rats. Amino Acids, 43(4): 1509-1523. http://dx.doi.org/10.1007/s00726-012-1225-y

Das, J., Roy, A., Sil, P.C., 2012. Mechanism of the protective action of taurine in toxin and drug induced organ pathophysiology and diabetic complications: a review. Food Funct., 3(12):1251-1264. http://dx.doi.org/10.1039/c2fo30117b

Davis, G., Anderson, K., Carroll, A., 2000. The effects of longterm caging and molt of Single Comb White Leghorn hens on heterophil to lymphocyte ratios, corticosterone and thyroid hormones. Poult. Sci., 79(4):514-518. http://dx.doi.org/10.1093/ps/79.4.514

Dawson, T.J., Maloney, S.K., Skadhauge, E., 1991. The role of the kidney in electrolyte and nitrogen excretion in a large flightless bird, the emu, during different osmotic regimes, including dehydration and nesting. J. Comp. Physiol. B, 161(2):165-171. http://dx.doi.org/10.1007/BF00262880

Deiana, M., Incani, A., Rosa, A., et al., 2008. Protective effect of hydroxytyrosol and its metabolite homovanillic alcohol on $\mathrm{H}_{2} \mathrm{O}_{2}$ induced lipid peroxidation in renal tubular epithelial cells. Food Chem. Toxicol., 46(9):2984-2990. http://dx.doi.org/10.1016/j.fct.2008.05.037

Gaucher, D., Arnault, E., Husson, Z., et al., 2012. Taurine deficiency damages retinal neurones: cone photoreceptors and retinal ganglion cells. Amino Acids, 43(5):1979-1993. http://dx.doi.org/10.1007/s00726-012-1273-3

Guan, Y.F., Breyer, M.D., 2001. Peroxisome proliferatoractivated receptors (PPARs): novel therapeutic targets in renal disease. Kidney Int., 60(1):14-30. http://dx.doi.org/10.1046/j.1523-1755.2001.00766.x

Hamden, K., Carreau, S., Jamoussi, K., et al., 2009. 1 $\alpha, 25$ Dihydroxyvitamin D3: therapeutic and preventive effects against oxidative stress, hepatic, pancreatic and renal injury in alloxan-induced diabetes in rats. J. Nutr. Sci. Vitaminol., 55(3):215-222. http://dx.doi.org/10.3177/jnsv.55.215

Hanna, J., Chahine, R., Aftimos, G., et al., 2004. Protective effect of taurine against free radicals damage in the rat myocardium. Exp. Toxicol. Pathol., 56(3):189-194. http://dx.doi.org/10.1016/j.etp.2004.08.004

He, G., Karin, M., 2011. NF-кB and STAT3 - key players in liver inflammation and cancer. Cell Res., 21(1):159-168. http://dx.doi.org/10.1038/cr.2010.183 
Hu, Q.H., Wang, C., Li, J.M., et al., 2009. Allopurinol, rutin, and quercetin attenuate hyperuricemia and renal dysfunction in rats induced by fructose intake: renal organic ion transporter involvement. Am. J. Physiol.-Renal., 297(4):F1080-F1091.

http://dx.doi.org/10.1152/ajprenal.90767.2008

Kadam, S., Prabhasankar, P., 2010. Marine foods as functional ingredients in bakery and pasta products. Food Res. Int., 43(8):1975-1980. http://dx.doi.org/10.1016/j.foodres.2010.06.007

Kaneko, N., Sugioka, T., Sakurai, H., 2007. Aluminum compounds enhance lipid peroxidation in liposomes: insight into cellular damage caused by oxidative stress. $J$. Inorganic. Biochem., 101(6):967-975. http://dx.doi.org/10.1016/j.jinorgbio.2007.03.005

Keller, S.A., Moore, C.C., Evans, S.L., et al., 2011. Activated protein $\mathrm{C}$ alters inflammation and protects renal function in sepsis. J. Surg. Res., 168(1):e103-e109. http://dx.doi.org/10.1016/j.jss.2011.01.008

Kumar, A., Takada, Y., Boriek, A.M., et al., 2004. Nuclear factor- $\mathrm{KB}$ : its role in health and disease. J. Mol. Med., 82(7):434-448. http://dx.doi.org/10.1007/s00109-004-0555-y

Lakshmi Devi, S., Anuradha, C., 2010. Mitochondrial damage, cytotoxicity and apoptosis in iron-potentiated alcoholic liver fibrosis: amelioration by taurine. Amino Acids, 38(3): 869-879.

http://dx.doi.org/10.1007/s00726-009-0293-0

Lin, S., Yang, J., Wu, G., et al., 2010. Preventive effect of taurine on experimental type II diabetic nephropathy. $J$. Biomed. Sci., 17(Suppl. 1):S46. http://dx.doi.org/10.1186/1423-0127-17-S1-S46

Miao, J.F., Zhang, Y.S., Huang, G.Q., et al., 2009. Polysaccharide nucleic acid of bacillus calmette guerin modulates Th1/Th2 cytokine gene expression in lipopolysaccharideinduced mastitis in rats. Agric. Sci. China, 8(8):10101018 . http://dx.doi.org/10.1016/S1671-2927(08)60308-9

Miao, J.F., Zhang, J.Q., Ma, Z.L., et al., 2013. The role of NADPH oxidase in taurine attenuation of Streptococcus uberis-induced mastitis in rats. Int. Immunopharmacol., 16(4):429-435.

http://dx.doi.org/10.1016/j.intimp.2013.05.007

Moinuddin, I., Leehey, D.J., 2008. A comparison of aerobic exercise and resistance training in patients with and without chronic kidney disease. Adv. Chronic Kidney Dis., 15(1):83-96. http://dx.doi.org/10.1053/j.ackd.2007.10.004

Mozaffari, M., Patel, C., Abdelsayed, R., et al., 2006. Accelerated $\mathrm{NaCl}$-induced hypertension in taurinedeficient rat: role of renal function. Kidney Int., 70(2): 329-337. http://dx.doi.org/10.1038/sj.ki.5001503

Nakagawa, T., Hu, H., Zharikov, S., et al., 2006. A causal role for uric acid in fructose-induced metabolic syndrome. Am. J. Physiol. Renal Physiol., 290(3):F625-F631. http://dx.doi.org/10.1152/ajprenal.00140.2005

Nirala, S.K., Bhadauria, M., 2008. Propolis reverses acetaminophen induced acute hepatorenal alterations: a biochemical and histopathological approach. Arch. Pharm. Res., 31(4):451-461. http://dx.doi.org/10.1007/s12272-001-1178-5

Nirala, S.K., Bhadauria, M., Shukla, S., et al., 2008. Pharmacological intervention of tiferron and propolis to alleviate beryllium-induced hepatorenal toxicity. Fund. Clin. Pharmacol., 22(4):403-415. http://dx.doi.org/10.1111/j.1472-8206.2008.00603.x

NRC (National Research Council), 1994. Committee on Rangeland Classification. Rangeland Health: New Methods to Classify, Inventory, and Monitor Rangelands. National Academies Press.

Oberg, B.P., Mcmenamin, E., Lucas, F.L., et al., 2004. Increased prevalence of oxidant stress and inflammation in patients with moderate to severe chronic kidney disease. Kidney Int., 65(3):1009-1016. http://dx.doi.org/10.1111/j.1523-1755.2004.00465.x

Parikh, V., Khan, M.M., Mahadik, S.P., 2003. Differential effects of antipsychotics on expression of antioxidant enzymes and membrane lipid peroxidation in rat brain. $J$. Psychiatr. Res., 37(1):43-51. http://dx.doi.org/10.1016/S0022-3956(02)00048-1

Ridder, D., Schwaninger, M., 2009. NF-кB signaling in cerebral ischemia. Neuroscience, 158(3):995-1006. http://dx.doi.org/10.1016/j.neuroscience.2008.07.007

Robins, A., Phillips, C., 2011. International approaches to the welfare of meat chickens. Worlds Poult. Sci. J., 67(2): 351-369. http://dx.doi.org/10.1017/S0043933911000341

Rodrigo, R., Rivera, G., 2002. Renal damage mediated by oxidative stress: a hypothesis of protective effects of red wine. Free Radical. Biol. Med., 33(3):409-422. http://dx.doi.org/10.1016/S0891-5849(02)00908-5

Rouach, H., Fataccioli, V., Gentil, M., et al., 1997. Effect of chronic ethanol feeding on lipid peroxidation and protein oxidation in relation to liver pathology. Hepatology, 25(2):351-355. http://dx.doi.org/10.1053/jhep.1997.v25.pm0009021946

Singh, D., Kaur, R., Chander, V., et al., 2006. Antioxidants in the prevention of renal disease. J. Med. Food, 9(4): $443-450$. http://dx.doi.org/10.1089/jmf.2006.9.443

Sun, M., Zhao, Y., Gu, Y., et al., 2012. Anti-inflammatory mechanism of taurine against ischemic stroke is related to down-regulation of PARP and NF-кB. Amino Acids, 42(5): 1735-1747. http://dx.doi.org/10.1007/s00726-011-0885-3

Tian, Y., Zou, B., Yang, L., et al., 2011. High molecular weight persimmon tannin ameliorates cognition deficits and attenuates oxidative damage in senescent mice induced by D-galactose. Food Chem. Toxicol., 49(8):1728-1736. http://dx.doi.org/10.1016/j.fct.2011.04.018

Toyama, K., Sugiyama, S., Oka, H., et al., 2010. Exercise 
therapy correlates with improving renal function through modifying lipid metabolism in patients with cardiovascular disease and chronic kidney disease. J. Cardiol., 56(2):142-146.

http://dx.doi.org/10.1016/j.jjcc.2010.06.007

Wang, C.P., Wang, Y., Wang, X., et al., 2011. Mulberroside a possesses potent uricosuric and nephroprotective effects in hyperuricemic mice. Planta Med., 77(8):786-794. http://dx.doi.org/10.1055/s-0030-1250599

Wicker, T., Robertson, J.S., Schulze, S.R., et al., 2005. The repetitive landscape of the chicken genome. Genome Res. 15(1):126-136. http://dx.doi.org/10.1101/gr.2438004

Wirleitner, B., Neurauter, G., Nagl, M., et al., 2004. Down-regulatory effect of $N$-chlorotaurine on tryptophan degradation and neopterin production in human PBMC. Immunol. Lett., 93(2-3):143-149. http://dx.doi.org/10.1016/j.imlet.2004.03.006

Wu, X., Kong, X., Zhou, Y., et al., 2012. Sesamin exerts renoprotective effects by enhancing NO bioactivity in renovascular hypertensive rats fed with high-fat-sucrose diet. Eur. J. Pharmacol., 683(1-3):231-237. http://dx.doi.org/10.1016/j.ejphar.2012.01.029

Yan, X., 2015. Molecular nutrition: basic understanding of the digestion, absorption, and metabolism of nutrients. $J$.
Zhejiang Univ.-Sci. B (Biomed. \& Biotechnol.), 16(6): 413-416.

http://dx.doi.org/10.1631/jzus.B1500130

\section{中文概要}

题 目: 日粮中添加牛磺酸对不同饲养方式蛋鸡肾脏功能 的影响

目 的: 饲喂牛磺酸和降低饲养密度对蛋鸡肾脏功能的影 响。

创新点: 通过研究日粮中添加牛磺酸对不同饲养方式蛋鸡 肾脏功能的影响, 证实日粮中添加牛磺酸和降低 饲养密度均能降低蛋鸡肾脏损伤程度。

方 法: 将 15000 只绿壳蛋鸡随机分成散养组、笼养低密 度组和笼养高密度组, 每组又分成对照组（正常 日粮）和实验组（日粮中添加 $0.1 \%$ 牛磺酸）。十 五天后, 无菌采集血液及肾脏组织, 分析组织病 理学变化、炎症介质水平、氧化及抗氧化水平等。

结 论: 结果表明, 降低饲养密度和日粮中添加牛磺酸可 以改善肾脏损伤, 促进生产, 提高蛋鸡健康和福 利水平。

关键词: 饲养模式; 福利; 牛磺酸; 蛋鸡; 肾脏损伤 